\title{
Doing Harm by Doing Good: latrogenic Effects of Early Childhood Enrollment and Promotion Policies
}

\author{
Samuel J. Meisels \\ The University of Michigan
}

\begin{abstract}
Recent national concerns about the educational achievement of U.S. students have resulted in an increased emphasis on readiness for school and, in combination with the pervasive effects of mandated standardized testing, have led to several enrollment and promotion practices that have negative consequences for young children. This paper examines the rationale and research data about four of these practices: raising the age at entry, retention in grade, extra-year and transition programs, and parental holding out from kindergarten. The problematic effects of these phenomena are identified, and their role in establishing a "four-tiered kindergarten" is described. An alternative approach to conceptualizing readiness that is free of these negative effects is presented.
\end{abstract}

Can kids flunk kindergarten? Yes, sir-especially where the law mandates tests for first grade.

In this way, Time magazine summarized the thoughts of many after the state of Georgia enacted a law requiring that children pass a test at the end of kindergarten in order to gain entry to first grade (Bowen, 1988). Although testing practices in Georgia have changed substantially since 1988 (Rogers \& Blount, 1990), attention to the issues of failure in kindergarten and pressures placed on young children as they begin school has grown. The Wall Street Journal printed a front-page story below the headline, "Tense Tots," claiming that some schools are so pressured that children are becoming

This research was supported in part by a grant from the John $D$. and Catherine T. MacArthur Foundation. I am grateful to Sylvia Jones for thoughts about defining readiness, to Fong-ruey Liaw for assistance with analyzing the NELS:88 data, and to Dorothy Steele for comments on an earlier version of the article. The opinions expressed are solely those of the author.

Correspondence and requests for reprints should be sent to Samuel J. Meisels, University of Michigan, School of Education, 610 E. University, Ann Arbor, MI 48109-0406. 
stressed and fearful: "Flash cards, computers, tests all day long take a toll on fast-track students." The article described situations in which children were "burning out by the age of ten" (Putka, 1988).

Reports of this kind, and others that have since been published in both local and national newspapers and magazines, may tend to overstate some issues. But it is no exaggeration to claim that in recent years changes in early childhood enrollment and promotion policies have become a source of significant concern to parents, professionals, and policymakers. These changes have been motivated by several trends affecting U.S. schools overall, most notably the view that early childhood education should focus on preparing students to be "ready" for elementary school.

The 1989 Education Summit serves as an excellent illustration of the ascendance of the readiness perspective. During this summit, and in the subsequent meetings of the National Governors' Association (NGA), early childhood school readiness was identified as a key national priority. The first of the six National Education Goals stated that "By the year 2000, all children in America will start school ready to learn" (National Governors' Association, 1990). The NGA has not elaborated extensively on how this goal should be achieved, but it clearly represents the widely accepted view that early childhood experiences are essential for later school success.

Although researchers have cautioned that the effects of early education are occasionally exaggerated (Farran, 1990), investments in early intervention are generally very sound (Infant Health and Development Program, 1990; Shonkoff \& Meisels, 1990). Problems arise, however, when early childhood programs are expected to achieve such goals as preparing children to succeed in school, but provide programs that are developmentally inappropriate. The rising numbers of early childhood retentions and the increase in extra-year early elementary programs reflect the problem of trying to force children to learn concepts, skills, and facts that are inconsistent with their developmental abilities and that are presented in ways that are unsuitable for young children's styles of learning (Bredekamp \& Shepard, 1989). The intentions of the framers of such programs may be well-founded, but the programs' effects-unintended or not-may have harmful, or iatrogenic, consequences. This situation led one legislator in Virginia to propose that a "Procrustes Award" be given to school districts that have the highest kindergarten failure rates and make the greatest effort to force young children to conform to rigid standards (Digilio, 1989).

Where do these Procrustean standards come from? It appears that one significant source is standardized testing-not necessarily in kindergarten, but certainly within the first 3 to 4 years of school. Standardized testing is more widespread today than at any previous time in our history, and it is also more widely accepted by the general public. In the 1989 nationwide Gallup education survey, $77 \%$ of those polled favored a national standardized testing program to measure academic achievement (Gallup Organization, 
1989). A nearly equal proportion stated their preference for a standardized nationwide examination prior to high school graduation.

In the past 10 years standardized testing has grown and prospered. The National Commission on Testing and Public Policy (1990) reported recently that the equivalent of more than $\mathbf{2 0}$ million school days is given over simply to taking standardized tests in elementary and secondary schools each year. The Commission further noted an increase in reported sales of tests and testing services at the elementary and secondary level to more than $\$ 100$ million, in 1988 dollars. This represents a threefold increase over the previous 3 decades. The Commission concluded that "overall, the direct costs to taxpayers for state and local testing plus indirect teacher costs total between $\$ 725$ million and $\$ 915$ million annually"' (National Commission on Testing and Public Policy, 1990, p. 17).

According to Gregory Anrig, president of ETS, 44 states require some form of minimum competency achievement testing in their elementary and secondary schools. Of these, 35 require the use of state-developed or stateselected tests with state-prescribed performance standards. Twenty-one states have testing requirements for high school graduation. In Anrig's words, this is "an extraordinary time for standardized testing in American education" (Anrig, 1990, p. 11).

Early childhood education has certainly not been immune from this proliferation of standardized testing. The National Academy of Sciences reports that prekindergarten tests are required in more than 16 states and are known to be used at district levels in more than 37 states (Gnezda \& Bolig, 1988). The Academy also notes that kindergarten exit/first grade entrance tests, also known as "promotional gates" testing, are in use in at least 5 states and in nearly $\mathbf{4 0}$ districts. Further, achievement testing is required in 9 states for first and second graders, and in 27 states for third graders.

The issue is not simply that young children are being exposed to standardized, objectively scored, whole group tests, although important enrollment and promotion decisions are based on these measures. Of even greater concern is that the tests represent both the consequence and symptoms of larger educational problems (see Catterall, 1989). These problems include concern with the educational achievement of U.S. students, declining test scores, increasing numbers of dropouts, higher rates of illiteracy, and unfavorable comparisons with students from other countries. In order to ameliorate these problems, it is assumed that academic standards must rise, curricula must change, and expectations must be increased. Standardized tests-particularly high-stakes tests upon which retention and promotion decisions are based (Madaus, 1988)-are prime indicators of success in achieving these goals, and as such they become the mechanism for controlling or at least influencing curriculum standards and enrollment and promotion practices in the upper grades as well as in early childhood (Meisels, 1989). The balance of this article will focus on several of these practices and 
policies; it will identify their prevalence, effects, and implications; and it will offer alternative strategies for reaching these goals.

\section{DISTURBING TRENDS AND IATROGENIC EFFECTS}

The reliance on standardized testing in kindergarten is only one element of a much larger set of issues and problems facing educators and parents today. As Walsh (1989) and Shepard and Smith (1989a) have pointed out, in addition to the proliferation of standardized testing in general and of readiness testing in particular, other disturbing trends include the following: Schoolentry age is rising, extra-year programs are expanding, retentions are increasing, and parents are holding out their children from kindergarten at an increasing rate. The prevalence of these trends can be seen as reactions to significant pressures for students to display "readiness" for school.

Unfortunately, these trends have not been examined with sufficient care to identify their unintended negative consequences-their iatrogenic effects. Iatrogenesis is a term used in medicine that typically describes unintended effects of treatment. An unintended effect of the drug, thalidomide, was phocomelia and other major birth defects, just as the drug diethylstilbestrol (DES) resulted in the iatrogenic effect of cervical cancer in the offspring of mothers who used this drug to prevent pregnancy problems.

The disturbing trends noted above have iatrogenic effects as well. While not physically deforming, these practices may alter the inner life of children and may reduce their chances for life success no less than the action of a severe biological hazard. As such, the dangers of these practices should be well-publicized, and their use curtailed. We will examine iatrogenic effects in four different, though related, phenomena: raising the age at entry, retentions, extra-year programs, and parental holding out.

\section{RAISING THE AGE AT ENTRY}

Children in traditional American schools begin kindergarten at about age 5. According to Engel (1989), this places the United States in the earlier portion of school-entry ages when compared with other countries. Engel notes that school-entry age is set at 6 for Russia, Switzerland, Australia, Japan, and West Germany. In Sweden children enter school at age 7, in England they begin school between 4 and 5 years of age, and in New Zealand children begin school on their fifth birthday, rather than on a specific uniform date in the fall.

Apparently, there is no "magic age" for starting school (see Karweit, 1988). Certainly, there is no evidence to support moving the entry age forward. A review by Proctor, Black, and Feldhusen (1986) found few negative effects and many positive consequences of beginning school early rather 
than late. In still another review, Smith and Shepard (1987) note that "the youngest child in a classroom achieves slightly lower than the oldest child" (p. 133). They point out that the oldest and youngest children are separated by about 9 percentile ranks on first-grade reading tests, but by third grade oldest and youngest are indistinguishable.

During the past 10 years the ages at which children start school have been moving back gradually in the United States, so that children are beginning school at older ages now than they were previously (Shepard \& Smith, 1986). In 1978, $29 \%$ of the states $(N=15)$ required that a child be 5 by September; in 1986 the number had risen to 26 , or $52 \%$ (Wolf \& Kessler, 1987). Examples of these changes are easily cited. The Virginia legislature revised its law in 1985 that permitted children who were 5 by December 31 to enter school. They "'rolled back," one month at a time, from December 31 so that by 1988 the birthdate for automatic eligibility became September 30 (Eads, Miller, Ellwein, \& Walsh, 1990). Indiana's cutoff date for kindergarten entry, which was September 1 in 1989, was moved back one month each year so that by 1992 a child had to be 5 by June 1 to gain automatic entry to kindergarten.

This attention to school-entry age appears to be interwoven with the issue of school readiness. The assumption is that the older the child, the more able the child will be to negotiate the requirements of the kindergarten curriculum. Proponents of older entry ages note that elementary school curricula have changed in recent years, becoming enmeshed in the descending academic spiral of "higher standards," accountability, and increased academic expectations. Thus, the belief has emerged that if students could begin school at an older age, they would be more competent academically. The legislator who framed Indiana's law stated, "With this bill, I predict the dropout rate is going to be down because the majority of our boys and girls will be socially and emotionally ready for school" (Associated Press, 1989 , p.7). Unfortunately, this assumption appears to be without foundation.

The emphasis on chronology obscures the fact that maturation is only one of many factors that have an impact on development. This focus on chronological age ignores important differences among children that result from environmental and genetic factors (Angoff, 1988). Further, variability within groups of children is normal, regardless of age. Children of identical chronological ages whose environments or genetic endowments are significantly different, may show markedly different abilities when they reach school. In any typical group of 5-year-olds there may be a developmental range of nearly 24 months. By moving the entry date earlier, so that the mean chronological age is older, only this overall range will be affected. Because of natural variability and the impact of early experiences, it is still possible that the oldest children in any given group may be developmentally less advanced than their younger classmates. 
Changing the age at entry appears to be a limited strategy if its goal is to enroll children in school who are more "ready." Indeed, negative implications may follow from a change in the age of entry. For example, moving back the entry date encourages those who wish to fashion a more academic, less developmentally appropriate curriculum, since such advocates may begin considering kindergarten-age children capable of doing what was once thought of as first-grade work. Further, by moving the age range up, more children will require an additional year of preschool or day care. This can represent not only an economic burden for parents of moderate and limited means, but also an increase on the demands for high-quality child care, although there are not enough high-quality child care slots available now (Meisels \& Sternberg, 1989). From a national policy perspective, such individuals will be deprived of one year in which they could be wage earners, as well as taxpayers.

Given the societal and familial inequities that many children encounter in their first few years of life (Schorr, 1988), age should remain a nondiscriminatory variable at the outset of school. Changing the age at entry will serve little purpose in the effort to improve the later school outcomes of young children, and may actually hinder these efforts.

\section{RETENTION}

Another strategy utilized by educators and decision-makers to increase the likelihood of school success is retention or failure in kindergarten or first grade. If children enter kindergarten or first grade unprepared for the curriculum, it is assumed that they should be given another year to ready themselves so that they will not encounter further failure as they move through the grades. Apparently, retention in kindergarten or first grade is considered preferable to retention in later grades.

The best-publicized example of this practice in recent years occurred in the state of Georgia from 1986 through 1988. The Georgia situation has been described in detail elsewhere (Meisels, 1989). Suffice it to say that the state of Georgia instituted a promotional gates testing program at the end of kindergarten and the end of Grade 3. A child was required to score above the 10th percentile on a state-adapted form of the California Achievement Test in kindergarten prior to enrollment in first grade; the child's teacher was also consulted about promotion decisions. More than $8.5 \%$ of the children to whom this test was administered in 1987-1988 "failed" it and were retained in grade. An additional $12.6 \%$ of Georgia's first graders were retained that same year (Southern Regional Education Board, 1990). Cities such as Minneapolis, New York, and Chicago have had similar benchmark testing programs for many years. But in every case these cities have retreated from the policy of early childhood retention and benchmark testing. 
Georgia, too, has altered its testing procedures in order to reduce the negative effects of its original testing program.

Nevertheless, retention rates are extremely high in elementary school in general and in the first years of school in particular. For example, the percent of children retained in first grade in nine southern states in 1987-1988 is as follows: Kentucky-5.1; North Carolina-7.7; Maryland-7.8; Virginia8.7; Florida-9.6; Texas-10.0; Georgia-12.6; Mississippi-13.6; and Louisiana-14.0 (Southern Regional Education Board, 1990). The state of Massachusetts reported that up to $20 \%$ of kindergarten and first-grade students are regularly recommended for retention in that state (Massachusetts Board of Education, 1990) although newly enacted state policies oppose this practice. In a survey of $\mathbf{4 0}$ urban school districts conducted for the Council of Great City Schools it was found that retention was widely practiced in $80 \%$ of the districts that responded (Gastright, 1989).

A common finding in many of these reports is that the burden of retention is spread unequally in terms of race and SES. The 1990 Condition of Education report to Congress by the U.S. Department of Education notes that among black 13 -year-olds, $44.2 \%$ of males and $35 \%$ of females were below grade by one or more years in 1985 (U.S. Department of Education, 1990). This compares with whites in which $29 \%$ of the males and $21 \%$ of the females were below grade. Although retentions and failures have increased for all groups since 1975, the below-grade-level rates have increased at nearly twice the rate for blacks as for whites in the past 15 years.

These findings are reflected in data from the stratified national sample included in the National Education Longitudinal Study of 1988 (NELS:88; National Center for Education Statistics, 1989). The NELS data show that $19.3 \%$ of the 16,623 white, black, and Hispanic public school students with complete data who were studied were retained at least once in kindergarten through eighth grade with $8 \%$ of these students being retained in kindergarten or first grade. Further, $29.9 \%$ of the black students, and $25.2 \%$ of the Hispanic students repeated a grade, as contrasted to only $17.2 \%$ of the white students. Overall, boys outnumbered girl repeaters $24 \%$ to $15.3 \%$; $33.9 \%$ of the repeaters were from the lowest SES quartile, as contrasted with 8.6\% from the highest quartile (Meisels \& Liaw, 1991).

Research regarding retention demonstrates that the effects of retention are cause for great concern. In an article published more than 20 years ago, retention was described as an "unjustifiable, discriminatory, and noxious educational policy"' (Abidin, Gollady, \& Howerton, 1971). Recent findings have not altered this verdict. They show that retained children perform more poorly in future academic work, and many of them drop out of school altogether (Holmes, 1989). As House (1989) notes, "being retained has as much to do with children dropping out as does their academic achievement. It would be difficult to find another educational practice on which the evidence is so unequivocally negative" (p. 209). 
Research findings regarding retention in kindergarten are no less pessimistic. In their book, Flunking Grades: Research and Policies on Retention, Shepard and Smith (1989b) note that kindergarten retention does not improve achievement, is not fundamentally different from retention in later grades in its consequences, and has harmful effects on socioemotional outcomes and the development of self-concept. Nevertheless, kindergarten retention continues to take place in significant numbers. A recent study in North Carolina reported an $8.6 \%$ kindergarten retention rate in that state (Bryant, Clifford, \& Peisner, 1990). In California data are available from a study of 310,000 third graders who were enrolled in public schools in 19851986. Kindergarten retention rates in California districts during that year ranged from $0 \%$ to $50 \%$ with $38 \%$ of the districts retaining between $5 \%$ and $10 \%$ of their kindergarteners. Statistical comparisons with nonretainees showed the following significant differences in the group of retained students $(p<.0001)$ : more boys, more Spanish- and Vietnamese-speaking children, more English as a Second Language (ESL) students, and more children with parents with unskilled occupations and low family incomes. The retained children, when contrasted to non-retainees, reported less school enjoyment and had lower achievement scores in third grade (Howes, 1987).

The unintended effects of retention are very important to investigate. Research shows that retention is the single most sensitive indicator of dropout potential in high school (Kreitzer, Madaus, \& Haney, 1989). Being retained by one grade may increase the risk of dropping out by $40 \%$ to $50 \%$ for urban school students; by two grades the risk may be increased to $90 \%$ (Mann, 1986). Further, as noted, retention policies are not applied equally across ethnic and racial groups. In 1986-1987, white students in Florida were underrepresented by nearly $9 \%$ among retained students, whereas black students were overrepresented by $7 \%$ and Hispanics by $2 \%$ (Richardson, 1989). It has also been reported that grade repetition is more prevalent among males than females (Shepard, 1989), and among learning disabled populations as contrasted to non-learning-disabled students (Zigmond \& Thornton, 1985). Further, it is expensive. Figures for the state of Florida show that 38,404 students were not promoted in K-3 in 1988-1989 (roughly $30 \%$ ). The total cost of educating those who repeated was $\$ 143,630,960$ (Florida Center for Children \& Youth, 1990).

In the NELS:88 study referred to earlier, comparisons of those who had been retained with those who had never been retained show that students who had never been retained spent less time in remedial classes; had higher grades; higher scores on reading, math, and science achievement tests; felt greater control of their lives; and demonstrated a more positive selfconcept. In the face of evidence as uniform as this, it is virtually impossible to defend retention as a policy designed to improve student outcomes for young children. The apparent rationale-to ensure that students are prepared to continue in school-is clear. However, the evidence demonstrates 
that retention not only is unsuccessful at achieving this goal, but also has iatrogenic effects that suggest it should be banished from the arsenal of educational treatments.

\section{EXTRA-YEAR PROGRAMS}

Extra-year programs go by many names. They are called Developmental Kindergartens, Kindergarten Plus, Transitional K-1, Pre-First, Junior First Grade, Begin-a-garten, and Young Fives Programs. Labeled in this or in any other way, transitional programs are designed to provide children who are academically, socially, emotionally, and/or physically "immature" with more time to grow and develop. Typically, these programs are implemented during the year prior to kindergarten or the year before first grade.

It is difficult to obtain data concerning the utilization of extra-year programs, because they are usually counted as regular kindergartens or first grades for the purposes of auditing by state agencies. However, they appear to be quite widespread. For example, in Florida more than 14 different names are used to describe these extra-year programs in kindergarten through Grade 3. In 1989-1990, 11,033 students in 38 different Florida counties were enrolled in these alternate programs. Approximately $4 \%$ of the students in kindergarten or first grade were in an extra-year program (Florida Department of Education, 1990). Data from the State of Michigan collected in 1984 showed that there were 161 developmental kindergartens serving 5,700 students at a cost of $\$ 3.4$ million per year (Michigan Department of Education, 1984). North Carolina's costs for retention and extrayear programs are in excess of $\$ 22$ million per year (Bryant et al., 1989). In 1986-1987, Virginia reported serving more than 18,000 extra-year kindergarten and first grade students at a cost greater than $\$ 73.5$ million (Eads, 1990). In other words, extra-year programs appear to be quite prevalent. Moreover they cost no less than a state or district's average per pupil cost. This excess cost can be justified only by the effectiveness of these programs.

How effective are they? Do they prevent failure in later years? Are students who are enrolled in transitional programs able to display higher achievement in later grades than those who were promoted without a 2-year alternative? Are there iatrogenic effects that should be identified? The research in this area, although limited, appears to provide answers to these questions.

Shepard (1989) lists several methodological problems found in most studies of transitional programs. Specifically, she points out that those students who are recommended for transition programs, and who then enroll in those programs, are rarely compared with students who were similarly recommended for transition programs but who enrolled in regular grades instead. Moreover, for an adequate comparison to be made, these two 
groups should be comparable in terms of race, sex, SES, and general academic ability. The problem of equivalence between groups is especially acute when one recognizes that transitional programs are frequently designed for students who are considered academically able but "immature." Students with academic problems are often promoted and then compared with students who are in extra-year programs, despite the confound in ability between these two groups. Nevertheless, the studies that meet Shepard's criteria find no benefit for either so-called immature or slow learner populations who were enrolled in extra-year programs. Indeed, she concludes that the effects of transition and extra-year programs are indistinguishable from the effects of retentions.

A recent study that coupled developmental kindergarten with developmentally appropriate classroom activities in elementary school showed that the academic benefits of 2-year kindergartens may persist until second grade (Banerji, 1990). But, by third grade, no differences in reading or math scores were found between children enrolled in developmental kindergarten and matched, non-developmental-kindergarten children.

Another study compared three demographically similar groups of children at the end of their first year in either an extra-year prekindergarten program, a kindergarten retention, or first grade (Mantzicopoulos \& Morrison, 1990). Results were virtually identical for retained and extra-year children on academic, visual-motor, and perceptual measures. Both retained and extra-year children lagged behind their promoted peers in achievement scores and in the number of identified behavioral, perceptual, and visualmotor problems. The authors conclude that, although teacher perceptions of retainees were less favorable than those of transition students, there are more similarities than differences between retainees and students in extrayear programs.

Recent findings from a statewide study of retained, pre-kindergarten extra-year, and pre-first grade extra-year students echo these results. Eads (1990) reported that, in groups matched for age, ethnicity, gender, SES, and kindergarten entry-test score, no advantage was conferred by an extra year in any of the above configurations. Indeed, the analyses show a "significant negative cognitive effect associated with transitional programs and kindergarten retention" (p. 4). "Junior Kindergarten" students who spent two years before reaching first grade fell behind their matched peers who had only one year of kindergarten. Similarly, retained students and students in transitional first grades fared poorly in comparisons with their matched peers. Moreover, extra-year programs increased disparities between minority and white children: "white male children placed in Junior Kindergarten scored about six points lower than their one-year-in-kindergarten counterparts. Black male children placed in Junior Kindergarten scored twice as much lower, with a twelve point margin between them and their one-year counterparts" (Eads, 1990, p. 3). In other words, these programs appear to 
be not only ineffective, but, similar to retention in so many ways, they appear to have extremely negative effects as well.

Given this perspective, one can speculate about why extra-year programs, as well as retentions, remain so prevalent. In both instances teachers, parents, and policymakers find themselves in a situation not entirely of their own making. As explained earlier, the downward spiral of academic demands, brought about in part by the demands of standardized testing in the early elementary grades, has resulted in teachers finding their students less able to cope with curricula that previously were directed toward older and more experienced students. In consequence, teachers appear to be more amenable to strategies that will remove children from situations in which they may fail. One Virginia supervisor of early childhood education noted that, "There's no doubt, we've pushed down the curriculum, and we have very academic first grades.... When you're a kindergarten teacher, you say, 'I don't want this child going on to that' "' (Digilio, 1990, p. B7). Extra-year programs represent one way to achieve this objective. However, as demonstrated by the research reviewed above, the very alternative selected to protect children from an increasingly inappropriate curriculum carries within it the seeds of failure, low self-esteem, and reduced achievement.

The iatrogenic effects of extra-year programs are obvious. Students spend an extra year in school and for some this increases their risk of dropping out. These programs are expensive to school districts, and although not shown to be effective, they draw funds from other programs that may be more efficacious. The students enrolled in extra-year programs often feel as if they have failed, and experience the same lack of self-confidence and impaired locus of control as other retained students. In short, extra-year programs have iatrogenic effects. They represent good intentions that are potentially harmful in implementation. The evidence does not support their continued utilization.

\section{PARENTAL HOLDING OUT}

In recent years a relatively quiet change in enrollment policies has begun to appear. Known as "holding out," this is the decision by parents to delay their children's entry into kindergarten by a year. Originally, kindergarten was a protected place-a garden of children. Froebel and Pestalozzi envisioned kindergarten as a unique environment that would form a bridge for children between home and the specialized demands of school (Braun \& Edwards, 1972). However, parents today appear to feel the need to protect their children from kindergarten by holding them out of school until they are 6 years old. In the past, parents who wanted to give their children an advantage would try to accelerate them; now they hold them back in order to get them ahead. 
In Colorado, Shepard and her colleagues studied hold-out patterns in 19 school districts (Shepard, Graue, \& Catto, 1989). They reported that $60 \%$ of the schools in their sample had a substantial number of over-age kindergarten students, accounting for between $10 \%$ and $64 \%$ of the kindergarten boys. Thirty percent of the schools studied had girls who were held out in numbers exceeding $10 \%$. Schools with early entry dates had less holding out, but evidence still existed that some parents held out boys with spring birthdays. Finally, they found that holding-out practices occurred much more frequently in high SES districts than in low SES districts.

A more in-depth study of one county-Marin County, Californiareported relatively similar findings. Mergendoller and his colleagues found that $23 \%$ of the boys and $12 \%$ of the girls in this county were over-age (Mergendoller, Bellisimo, \& Horan, 1990). When they excluded retentions from this group, they found that $18 \%$ of the boys and $9 \%$ of the girls had been held out by their parents. Moreover, there was a high association between holding out and high SES for boys. For girls, it appeared that the extent to which a program was considered developmentally appropriate by the parents was the variable that was most highly associated with holding out, with less developmentally appropriate programs having higher rates of holding out for girls.

The findings from Marin were replicated by an independent study conducted in another high SES area, Grosse Pointe, Michigan. In a study of two grade cohorts, approximately $20 \%$ of the boys and $10 \%$ to $13 \%$ of the girls were found to have been held back by their parents from entry into kindergarten during their first eligible year (McCaig, 1990). When the school year was divided into a younger and an older half, with June to November the dividing point for the "young" half, it was reported that $33 \%$ of the boys born in the "young" half of the year were held out and fewer than $10 \%$ of boys born during the "old" half of the year were held back. About $20 \%$ of the girls born during the "young" half were held back; practically no girls in the "old" half were held back.

What are the implications of the hold-out phenomenon? First, the chronological range in the average classroom expands from 12 months to 24 months, meaning that the oldest child may be $30 \%$ older than the youngest at kindergarten entry. The problems posed for a teacher by this type of age span are nearly monumental, especially since economically advantaged families are more likely to hold out their children. Thus, the most advantaged children are those who are the oldest, and the least advantaged are the youngest.

A second problem concerns curriculum. As the kindergarten group grows older through holding out, the focus of instruction typically shifts upward in response to the needs of the older students and the expectations of their parents. Ironically, this contributes to the escalation of academic 
demands that brought parents and some professionals to recommend holding out originally.

The third problem implied by large-scale holding out is the disruption caused to school districts' efforts to establish equity in their classrooms. Because of holding out, first graders who are barely 6 years old are compared with 71/2-year-olds on standardized tests, and must compete with older children in the same grade for parts in dramatic productions or even for places on sports teams. Given that higher income families can more easily afford to keep their children in day care or preschool for another year, it is clear that holding out truly makes a bad situation worse by accentuating the negative effects of social class. Finally, holding out ignores the axiom that the most sensitive indicator of dropout potential is age/grade correspondence. To the extent that a student is too old for grade, that student's chances of graduating from high school are reduced dramatically. It is possible that middle- to upper-income students who have been held out will form a subgroup of over-age students who will not be at risk for dropping out in the same way as other students, but this is yet to be demonstrated.

Only six states in the United States currently require that students attend kindergarten (Delaware, Florida, Kentucky, Louisiana, South Carolina, and South Dakota), although nearly all states offer a kindergarten option. It is possible that as a result of the holding-out phenomenon, parental choice may be curtailed as more states may make kindergarten entry by age five mandatory in order to bring order to the beginning of school. This represents yet another misguided policy that is well-intentioned in origin and that is designed to give children an advantage at the outset of school. Yet, it is clear that this approach provokes more harm than good, as is the case with raising the age at entry, relying on early childhood retentions, and expanding the use of extra-year programs.

\section{THE FOUR-TIERED KINDERGARTEN}

The policies described above were introduced in order to respond to nationwide pressures for "excellence," accountability, and increased competitiveness. Unfortunately, they have had more negative effects than positive outcomes. Compared to other possible alternatives, their iatrogenic potential far outweighs their probability of helping children become more ready for school. These unintended negative effects include a downward escalation of academic demands; increased economic burden on parents, local districts, and states; higher probability of dropping out; lowered student self-esteem; impaired academic achievement; exaggerated social-class differences; increased racial inequities; and confused messages to parents.

The data presented earlier show that the phenomena under discussion are quite widespread. Moreover, they do not necessarily occur singly; they are 
often found in combination. A school district in a state with a recently raised entry age may retain a significant proportion of their children, enroll some of them in an extra-year prekindergarten or pre-first-grade program, and still find that some parents will hold their children out regardless of the official age at entry. In short, we are witnessing the emergence of a four-tiered kindergarten.

The first tier is composed of regular age-appropriate entry children, although entry age is moving up nationally in response to more-academic and less-developmentally appropriate curricula. In this not-so-hypothetical classroom, approximately half of the students may be found in this group. The second tier are the students who are held back. Consisting of $15 \%$ to $20 \%$ of the children in some school districts, nonpromoted students stand to gain little from repeating kindergarten. Although there are exceptions to this statement, in which occasionally an individual child may be held back after extensive discussions between the child's parents, teacher, and school administrators, there is no justification for the large-scale policies of retentions taking place today.

The third tier consists of extra-year students. As many as $10 \%$ to $15 \%$ of kindergarten students in some districts are already in their second year of public school. These children have more in common with their retained counterparts than their other classmates. This commonality can be found in the likely negative effects of their school-entry experience, despite the fact that they spent their first year in an "Early Fives," or a "Developmental K" classroom, rather than in the regular kindergarten. Finally, the fourth tier is composed of those who were held out by their parents. Beginning school a year older than the "regular entry" students, these children comprise about $10 \%$ of the enrollment, have had an extra year of preschool or day care, are generally from mid- to high-SES families, and are more often male than female.

No educator or policymaker would rationally choose to create a set of stratifications like this. Any one of these phenomena has problematic consequences. But taken in combination they imply a situation in which sound pedagogical principles cannot be followed, early tracking by academic ability will be reinforced, and successful school outcomes for many will become unattainable. Of all the objections, perhaps none is more telling than that raised by the father of a child with a mid-August birthdate who was denied entry to an Indiana kindergarten (the entry age had just been lowered to August 1). He argued that "Indiana's solution to the problems of the system is to exclude students in order to make the system work, rather than modify the system to meet the needs of the students." Clearly other solutions should be tried.

Taken singly or in combination, the four "tiers" represent a modern redefinition of the perennial developmental opposition between nature and 
nurture. In this modernist, high-stakes conception of the nativist position, the task is one of protecting students from the rigid academic demands of later grades by holding them back, holding them out, entering them later, or adding another year of preparation. In contrast, the nurturist position contends that the academic curriculum of the later grades should be made flexible enough to adjust to the needs of students who are developing naturally at differential rates (see Banerji, 1990).

Such organizational solutions as those discussed in this article reflect a "nativist" approach. They assume that the school curriculum and organization is as monolithic and unchangeable as an individual's genetic endowment and biological inheritance. Traditional "readiness" programs, which are often little more than early childhood "prep" programs, rely on such external modifications as lowered entry dates and frequent retentions because they focus narrowly on preparing children to conform to the school curriculum and mistakenly believe that older students will become "better" students. The research literature about these programs-none of which contains as much diversity or as many stratifications as the "four-tiered kindergarten"- -shows that their short- and long-term effectiveness is quite limited (Schweinhart, Weikart, \& Larner, 1986). There is, however, extensive research on the effectiveness of comprehensive intervention programs with young disadvantaged and at-risk children (Farran, 1990). Typically, these programs are not "readiness" programs in the narrow connotation conveyed above. Rather, the effective programs that are described in the literature are those that are child- and family-focused, individualized and flexible, and developmental in orientation. They view growth as multidimensional, reflecting the child's culture, family, and environment. They are not maturational in orientation, but are responsive to individual variability, being based on reciprocal interchange between the child and the educational milieu.

\section{MINIMIZING IATROGENIC EFFECTS OF READINESS PROGRAMS}

As the enrollment and promotion policies that have been critiqued in this article are altered or eliminated, the role of a reconceptualized "readiness program" becomes all the more important. The curriculum of such a program would focus on a child's current skill accomplishments, knowledge, and life experiences, and then proceed in a differentiated way to extend a child's mastery to different and more complex levels. Readiness in this context is defined as mastery of those simpler skills that permit one to reach higher skills (Bruner, 1966). But since different children are ready for different experiences, the challenge facing schools is to identify an individual's level of readiness in a specific area and then provide a school environment 
that best matches the child's current status and future growth. In short, a developmentally appropriate approach to readiness is one that is relative, acknowledging that different children come to school prepared for different experiences; holistic, including an affective component that facilitates a child's successful interaction with the school milieu; comprehensive, extending well beyond the typical reading readiness and behavioral compliance expectations of traditional programs to include a focus on active learning and developmental objectives; and bi-directional, focusing both on children's capacities for learning and on schools' abilities to meet the individual needs of their students.

An important corollary of these assumptions concerns standardized testing. A program of early education that minimizes the harm described in this article must change its approach to assessment from past practice and must alter the sampling frame of what is measured.

Standardized, whole group, objectively scored achievement tests are of little utility for young children. Unless their effectiveness can be demonstrated, they should be curtailed or eliminated at least before third grade. Nevertheless, the process of individualized instruction is one that relies intrinsically on a continuous assessment of student learning, and that is influenced and modified significantly by children's responses to curricular innovation (see DeVries \& Kohlbert, 1987). It is essential that assessment take place in early childhood classrooms, but this assessment should differ from typical "readiness" or achievement testing. Readiness tests that are available today are concerned with a child's relative preparedness for a specific academic or preacademic program (Meisels, 1987). They rarely contain items that are developmental in orientation. Rather, they assess what a child knows when he or she comes to school. If the child has not been taught or has not experienced what is on the test, then the child will not do well. A "failing" score on such a test indicates little about a child's potential to acquire skills. It generally tells us only about the child's specific skill acquisition. Hence, in formulating a readiness program that is concerned with the whole child, and not a narrow set of specific learned accomplishments, it will be necessary to devise assessments that evaluate student learning authentically and that document the curriculum being implemented.

In other words, the "sampling frame" for assessments must be both broadened and deepened. Readiness and achievement tests focus on a very narrow range of numeracy, literacy, and self-help skills. To reflect a diverse curriculum adequately, this "frame" must be changed to include a much broader range of experiences that sample the curriculum more fully than do typical readiness and achievement tests. Further, it must be deepened to encompass diverse types of information (e.g., criterion-referenced checklists, work samples or portfolios, and systematic teacher-report forms). "Measurement-driven instruction" (Koretz, 1988; Madaus, 1988) must give way 
to instruction-driven measurement in which individual differences are viewed by teachers not as deficits used to justify retentions and extra-year assignments, but as hypotheses used to construct individualized programs. In this way, the lines between instruction and assessment are blurred in a productive manner.

No single kindergarten or prekindergarten curriculum can achieve all of these goals. But, the solution to incorporating individual variability into the classroom does not lie in devising Procrustean solutions that produce more negative effects than positive outcomes. Instead of focusing on a single year or two of early schooling, it is essential to consider the first several years of school as part of an overall readiness/intervention system. (See the National Association of State Boards of Education's 1988 recommendation of an "early childhood unit" in elementary schools.) Needed is not a single intervention, but a structural reorganization that will meet the needs of the diverse students entering schools today. The simplistic addition of extra time by means of retentions, extra-year programs, changes in entry age, or holding out will not accomplish these goals. Rather, the reorganization that is called for would reach out in several directions simultaneously: to early elementary grades, to parents, to preschools, to the community, to assessment specialists, and to public and private sources of support. Most important, such an approach would reach out to individual children, asserting their right to be treated fairly, flexibly, and with knowledge of the developmental differences implicit in their early school and life experiences.

\section{REFERENCES}

Abidin, R., Golladay, W., \& Howerton, A. (1971). Elementary school retention: An unjustifiable, discriminatory and noxious educational policy. Journal of School Psychology, 9, 410-417.

Angoff, W.H. (1988). The nature-nurture debate, aptitudes, and group differences. American Psychologist, 43, 713-720.

Anrig, G.R. (1990). Standardized testing-Now and in the future. Harvard Graduate School of Education Bulletin, 34, 11-12.

Associated Press. (1989, September 11). More states ban 4-year-olds from school. The PostTribune, p. 7.

Banerji, M. (1990, April). Longitudinal effects of a two-year developmental kindergarten program on academic achievement. Paper presented at the annual meeting of the American Educational Research Association, Boston, MA.

Bowen, E. (1988, April 25). Can kids flunk kindergarten? Yes, sir-especially where the law mandates tests for first grade. Time, p. 86.

Braun, S.J., \& Edwards, E.P. (1972). History and theory of early childhood education. Worthington, $\mathrm{OH}$ : Charles A. Jones.

Bredekamp, S., \& Shepard, L. (1989). How best to protect children from inappropriate school expectations, practices, and policies. Young Children, 44, 14-24.

Bruner, J.S. (1966). Toward a theory of instruction. Cambridge, MA: Harvard University Press. 
Bryant, D.M., Clifford, R.M., \& Peisner, E.L. (1990). Developmental appropriateness in kindergarten. American Research Journal, 28, 783-803.

Catterall, J. (1989). Standards and school dropouts. American Journal of Education, 98, 1-34.

DeVries, R., \& Kohlberg, L. (1987). Programs of early education: The constructivist view. Boston: Longman.

Digilio, A. (1989, December 2). Kindergarten award with Procrustean air. Washington Post, pp. B1, B7.

Digilio, A. (1990, May 26). Remedial kindergarten may harm students. Va. report says. Washington Post.

Eads, G.M. (1990). Kindergarten retention and alternative kindergarten programs (A report to the Virginia Board of Education). Unpublished manuscript, Virginia Department of Education, Richmond.

Eads, G.M., Miller, A.K., Ellwein, M.C. \& Walsh, D.J. (1990, April). Testing for kindergarten readiness: State action and district response. Paper presented at the annual meeting of the American Educational Research Association, Boston, MA.

Engel, P. (1989, June). Assessment of kindergartners' readiness for first grade: Policies and practices of industrialized nations. Paper presented at the annual assessment conference of the Education Commission of the States, Boulder, CO.

Farran, D. (1990). Effects of intervention with disadvantaged and disabled children: A decade review. In S.J. Meisels \& J.P. Shonkoff (Eds.), Handbook of early childhood intervention (pp. 501-539). New York: Cambridge University Press.

Florida Center for Children and Youth. (1990). Key facts about the children. Tallahassee: Author.

Florida Department of Education. (1990). 1990 survey of alternate placement programs in Florida-Kindergarten through grade 3. Tallahassee: Author.

Gallup Organization. (1989). Opinions on national testing in the schools. Cited in the New York Times, December 26, 1989.

Gastright, J.F. (1989, March). The nation reacts: A survey of promotion/retention rates in 40 urban school districts. Paper presented at the annual meeting of the American Educational Research Association, San Francisco, CA.

Gnezda, M.T., \& Bolig, R. (1988). A national survey of public school testing of prekindergarten and kindergarten children. Washington, DC: National Academy of Sciences.

Holmes, C.T. (1989). Grade level retention effects: A meta-analysis of research studies. In L.A. Shepard \& M.L. Smith (Eds.), Flunking grades: Research and policies on retention (pp. 16-33). Philadelphia: The Falmer Press.

House, E.R. (1989). Policy implications of retention research. In L.A. Shepard \& M.L. Smith (Eds.), Flunking grades: Research and policies on retention (pp. 202-213). Philadelphia: The Falmer Press.

Howes, C. (1987). State of California retention data. In California State Department of Education, Here they come: Ready or not! (Report of the School Readiness Task Force). Sacramento: California State Department of Education.

Infant Health and Development Program. (1990). Enhancing the outcomes of low-birthweight, premature infants. Journal of the American Medical Association, 263, 30353042 .

Karweit, N. (1988). Quality and quantity of learning time in preprimary programs. The Elementary School Journal, 89, 119-133.

Koretz, D. (1988). Arriving in Lake Wobegon: Are standardized tests exaggerating achievement and distorting instruction? American Educator, 12, 8-15, 46-52.

Kreitzer, A.E., Madaus, G.F., \& Haney, N. (1989). Competency testing and dropouts. In L. Weis, E. Farrar, \& H.G. Petrie (Eds.), Dropouts from school: Issues, dilemmas, and solutions (pp. 129-152). Albany: State University of New York Press.

Madaus, G.F. (1988). The influence of testing on the curriculum. In L.N. Tanner (Ed.), Critical issues in curriculum. 87th Yearbook of the National Society for the Study of Education (pp. 83-121). Chicago: University of Chicago Press. 
Mann, D. (1986). Can we help dropouts: Thinking about the undoable. In G. Natriello (Ed.), School dropouts: Patterns and policies. New York: Teachers College Press.

Mantzicopoulos, P., \& Morrison, P. (1990). Characteristics of at-risk children in transitional and regular kindergarten programs. Psychology in the Schools, 27, 325-332.

Massachusetts Board of Education. (1990). Structuring schools for success: A focus on grade retention. Quincy: Author.

McCaig, R. (1990). The practice of holding back children from entry to kindergarten. How widespread is it? Unpublished manuscript, Grosse Point (MI) Public School System.

Meisels, S.J. (1987). Uses and abuses of developmental screening and school readiness testing. Young Children, 42, 4-6, 68-73.

Meisels, S.J. (1989). High-stakes testing in kindergarten. Educational Leadership, 46, 16-22.

Meisels, S.J., \& Liaw, F. (April, 1991). Failure in grade: Do retained students catch up? Paper presented at the annual meeting of the American Educational Research Association, Chicago, IL.

Meisels, S.J., \& Sternberg, L.S. (1989, June). Quality sacrificed in proprietary child care. Education Week, 8, 36.

Mergendoller, J.R., Bellisimo, Y., \& Horan, C. (1990, April). Kindergarten holding out: The role of family background, school characteristics, and parental perceptions. Paper presented at the annual meeting of the American Educational Research Association, Boston, MA.

Michigan Department of Education. (1984). Superintendent's study group on early childhood education. Unpublished manuscript.

National Association of State Boards of Education. (1988). Right from the start. Washington, DC: Author.

National Center for Education Statistics. (1989). National Education Longitudinal Study of 1988. Washington, DC: Author.

National Commission on Testing and Public Policy. (1990). From gatekeeper to gateway: Transforming testing in America. Chestnut Hill, MA: Boston College.

National Governors' Association. (1990). National education goals. Washington, DC: Author.

Proctor, T.B., Black, K.N., \& Feldhusen, J.F. (1986). Early admission of selected children to elementary school: A review of the research literature. Journal of Educational Research, $80,70-76$.

Putka, G. (1988, July 6). Tense tots: Some schools press so hard kids become stressed and fearful. The Wall Street Journal, pp. 1, 6-7.

Richardson, G.L. (1989). Student retention: Implications for dropout prevention programs. Tallahassee, FL: Bureau of Education for Exceptional Children.

Rogers, W., \& Blount, J.E. (1990, April). Georgia's first-grade reading assessment: The historical perspective. Paper presented at the annual meeting of the American Educational Research Association, Boston, MA.

Schorr, L.B. (1988). Within our reach: Breaking the cycle of disadvantage. New York: Doubleday Anchor Press.

Schweinhart, L.J., Weikart, D.P., \& Larner, M.B. (1986). Consequences of three preschool curriculum models through age 15. Early Childhood Research Quarterly, 1, 15-45.

Shepard, L.A. (1989). A review of research on kindergarten retention. In L.A. Shepard \& M.L. Smith (Eds.), Flunking grades: Research and policies on retention (pp. 64-78). Philadelphia: The Falmer Press.

Shepard, L.A., Graue, M.E., \& Catto, S.F. (1989, March). Delayed entry into kindergarten and escalation of academic demands. Paper presented at the annual meeting of the American Educational Research Association, San Francisco, CA.

Shepard, L.A., \& Smith, M.L. (1986). Synthesis of research on school readiness and kindergarten retention. Educational Leadership, 44, 78-86.

Shepard, L.A., \& Smith, M.L. (1989a). Academic and emotional effects of kindergarten retention in one school district. In L.A. Shepard \& M.L. Smith (Eds.), Flunking grades: Research and policies on retention (pp. 79-107). Philadelphia: The Falmer Press. 
Shepard L.A., \& Smith, M.L. (Eds.), (1989b). Flunking grades: Research and policies on retention: Philadelphia: The Falmer Press.

Shonkoff, J.P., \& Meisels, S.J. (1990). Early childhood intervention: The evolution of a concept. In S.J. Meisels \& J.P. Shonkoff (Eds.), Handbook of early childhood intervention (pp. 3-31). New York: Cambridge University Press.

Smith, M.L., \& Shepard, L.A (1987). What doesn't work: Explaining policies of retention in the early grades. Phi Delta Kappan, 69, 129-134.

Southern Regional Education Board. (1990). Reaching the goal of readiness for school. Atlanta: Author.

U.S. Department of Education. (1990). Condition of Education 1990: A Report to Congress. Washington, DC: Author.

Walsh, D.J. (1989). Changes in kindergarten. Why here? Why now? Early Childhood Research Quarterly, 4, 377-399.

Wolf, J.M., \& Kessler, A.L. (1987). Entrance to kindergarten: What is the best age? Arlington: VA: Educational Research Service.

Zigmond, N., \& Thornton, H. (1985). Follow up of post-secondary age learning disabled graduates and dropouts. Learning Disabilties Research, 1, 50-55. 